AGRICULTURE AND BIOLOGY JOURNAL OF NORTH AMERICA

ISSN Print: 2151-7517, ISSN Online: 2151-7525

(C) 2011, ScienceHuß, http://www.scihub.org/ABJNA

\title{
Lactobacillus delbruekii infection of Clarias bidorsalis cultured in fish tanks in llorin, Kwara state-Nigeria
}

\author{
Chioma G. Nzeh ${ }^{1}$ and Augustine O. Udeze ${ }^{2}$ \\ ${ }^{1}$ Department of Zoology, University of Ilorin, Ilorin-Nigeria \\ ${ }^{2}$ Department of Microbiology, University of Ilorin, Ilorin-Nigeria
}

\begin{abstract}
Specimens of Clarias bidorsalis which were cultured in tanks were fed with extruded imported feed between September 2008 and June 2009. Some of the specimens developed ulcers on their bodies. The ulcers at first appeared red in colour and eventually turned white on their skin and fins which later resulted in the death of the specimens. The diseased fishes and the water samples were used for bacteriological analysis. Nutrient agar and eosin methylene blue (EMB) media were used for the isolation of the bacteria. Cultural, morphological and biochemical characteristics were used for the identification of the isolates. The three bacteria isolates identified are; Lactobacillus delbruekii, Bacillus alvei and Lactobacillus sp. Application of Koch's postulate showed that $L$. delbruekii caused a similar disease condition in experimental set-up which eventually resulted in the death of the fish after two days thereby strongly suggesting $L$. delbruekii as the aetiologic agent. $B$. alvei and Lactobacillus $s p$ however did not produce any noticeable disease condition after 7 days of careful observation. It is therefore suggested that $L$. delbruekii becomes pathogenic to fish with change in water quality due to high organic load.
\end{abstract}

Keywords: Clarias bidorsalis, disease, Lactobacillus delbruekii, Bacillus alvei

\section{INTRODUCTION}

Water medium harbours some bacteria. These bacteria are normally free living inside the water but are capable of adopting a pathogenic role under certain circumstances (Harishi et al., 2003). They are referred to as opportunistic pathogens. Many of these organisms are saprophytes living on dead organic matter such as plants and animals but bacterial infection in fish results because of changes in the bacteria/fish relationship (Austin and Allen, 1985).Fish in intensive culture are continuously affected by environmental fluctuations and management practices such as handling, crowding, transporting, drug treatments, undernourishment, fluctuating temperatures, and poor water quality. All of these factors can impose considerable stress on the homeostatic mechanisms of fish rendering them susceptible to a wide variety of pathogens.

When the number or the virulence of the pathogen increases or the hosts resistance is reduced, the pathogen may be able to cause disease in the fish (Fish Doc. 2004). The pre-disposing factor which results in these bacteria becoming problematic is stress caused by poor water quality, poor nutrition and handling. Thus, disease may result from bad husbandry and poor water quality condition, which debilitates the fish and leave them vulnerable to infections by opportunistic pathogens (Austin and Allen, 1985). The most troublesome bacteria in African catfish are facultative and opportunistic. Among the bacteria reported are Aeromonas hydrophila and Pseudomonas spp. Myxobacteria causing fin rot in fish has also been reported in African catfish.

Clarias $\mathrm{sp}$ is one of the cultured species in Nigeria. Although it is scale less, it has special adaptations; the presence of accessory breathing organs which enables it to survive in water with low oxygen content. There are different types of culture systems used in rearing Clarias such as tanks and ponds. Large numbers of fish species are fed with formulated diets and the feed that are not eaten by the fishes pollute the water, resulting in poor water quality. High organic content of water encourages the growth of bacteria.

When the numbers or the virulence of the pathogen increases or the host resistance is reduced, the pathogen may be able to succeed in establishing an infection. Some of the reported works on infections in fishes include Angka, et al. (1995), they observed virulence characteristics of Aeromonas hydrophila in which $A$. hydrophila killed Clarias gariepinus after five days. In Nigeria, Oladosu et al. (2007) also demonstrated the pathogenicity of Bacillus $s p$. to 
fishes. Species have also been isolated from diseased or healthy fish. They were considered part of the normal fish gut microflora (Michel et al., 1986). Ross and Toth (1974) reported that a chronic disease of adult Salmonids referred to as 'Pseudo-kidney' disease was caused by a member of this genus. Lactobacillus is found in diary products, meat, water, sewage, fruits and many other surfaces(Willey et al.2008) It is also used in industrial fermentation of milk and they are part of the normal floraof the mouth and intestinal tract of human body(Willey et al.2008) It has been observed among fish of the Pacific North-west region of America (Hiu et al., 1984). Some other reports indicated that fish-pathogenic lactobacilli or similar strain have broader geographical distribution. It occurs in Western Europe (Austin, 1980; Cone, 1982; Herman et al., 1985). Harishi et al 2003 demonstrated the prevalence of opportunistic pathogens in water. However in Nigeria reported work on bacterial infections in cultured fish species is still very scanty. This work reports on bacterial infections of cultured Clarias bidosarlis.

\section{MATERIALS AND METHODS}

Five hundred fry of Clarias bidorsalis were distributed into four 1000 litres fish tanks. These fishes were fed with extruded feed at $4 \%$ of their body weight at two feeding per day at $8.00 \mathrm{~h}$ and $18.00 \mathrm{~h}$. Water used in holding the fish was changed after three days and replaced with fresh water. About 30 days into the research it was observed that some of these fishes developed reddish patches on the skin and fins which later turned whitish in colour leading to the death of the fishes after 5-7 days of the appearance of the reddish patches.

The dead fish and water sample were taken to the laboratory for analysis.

\section{Isolation of bacteria from fish and water}

Sterilization of materials: All glassware were washed with detergent and rinsed with distilled water properly. These were then air dried before wrapping with aluminium foil and sterilized in hot air oven at $170^{\circ} \mathrm{C}$ for $2 \mathrm{hrs}$. Prepared media such as nutrient agar and EMB were sterilized in an autoclave at $121^{\circ} \mathrm{C}$ for 15 minutes. The inoculating loop was sterilized by heating in Bunsen flame. The inoculating loop was also sterilized by heating to redness using naked flame before and after each use.

Collection of specimens: The infected fish was collected in a sterile polythene bag while $100 \mathrm{ml}$ (stock-1) of water from the fish tank was collected with sterile conical flask and taken to the laboratory immediately for analysis.

Specimen preparation: One (1) gram of the infected fish was sectioned from the site of the necrosis and macerated aseptically using sterile pestle and mortar. Nine (9) $\mathrm{ml}$ of sterile distilled water was added and mixed thoroughly to form a homogeneous mixture (stock-2)

Ten-fold serial dilution in the ranges $10^{-1}$ to $10^{-6}$ of both stocks-1 and 2 were prepared using sterile distilled water. One (1) $\mathrm{ml}$ of sample dilutions were each plated on nutrient agar and EMB media and incubated at $37^{\circ} \mathrm{C}$ for $24 \mathrm{hrs}$.

Identification of isolates: The isolates were subcultured continuously until a pure culture is obtained. The isolates were subjected to series of biochemical tests such as catalase, coagulase, oxidase, endospore staining, motility, citrate utilization, starch hydrolysis, urease activity, glucose fermentation, sucrose fermentation, lactose fermentation, indole production, methyl red-Voges Proskeur and Mannitol fermentation tests as described by Cheesbrough, (1992). The isolates were further identified as described by Holt et al., (1994)

\section{RESULTS}

Based on morphological characteristics and biochemical tests (Table 1), three bacteria isolates were identified. They include Lactobacillus delbruekii, Bacillus alvei, and Lactobacillus sp.

Table 1: Biochemical reactions of bacteria isolates

\begin{tabular}{|c|c|c|c|}
\hline \multirow[t]{2}{*}{ TESTS } & \multicolumn{3}{|c|}{ REACTIONS } \\
\hline & B. alvei & L. delbruekii & L. sp \\
\hline $\begin{array}{l}\text { Grams reaction } \\
\text { and cell shape }\end{array}$ & $\begin{array}{l}+ \text { rods } \\
\text { (singly) }\end{array}$ & $\begin{array}{l}+ \text { rods } \\
\text { (chains) }\end{array}$ & $\begin{array}{l}+ \text { rods } \\
\text { (singly) }\end{array}$ \\
\hline Motility & - & + & + \\
\hline Endospore & + & - & - \\
\hline Catalase & - & - & - \\
\hline Coagulase & - & - & - \\
\hline Oxidase & + & + & + \\
\hline Citrate utilization & - & - & + \\
\hline Starch hydrolysis & + & - & + \\
\hline Urease & + & + & + \\
\hline $\begin{array}{l}\text { Glucose } \\
\text { fermentation }\end{array}$ & $+(\mathrm{NG})$ & $+(\mathrm{NG})$ & $+(\mathrm{NG})$ \\
\hline $\begin{array}{l}\text { Sucrose } \\
\text { fermentation }\end{array}$ & - (NG) & - (NG) & $+(\mathrm{NG})$ \\
\hline $\begin{array}{l}\text { Lactose } \\
\text { fermentation }\end{array}$ & - (NG) & - (NG) & $+(\mathrm{NG})$ \\
\hline Indole production & - & - & - \\
\hline Voges Proskeur & + & - & - \\
\hline $\begin{array}{l}\text { Mannitol } \\
\text { fermentation }\end{array}$ & - & - & - \\
\hline
\end{tabular}




\section{DISCUSSION}

Two bacteria isolates were identified namely Lactobacillus delbruekii and Bacillus alvei. Application of Koch's postulate showed that $L$. delbruekii caused a similar disease condition in an experimental set up which eventually resulted in the death of the specimen. $L$. spp are sometimes found in water and it is also used in the industrial fermentation of milk (Willey et al., 2008). It is plausible that the remains of feed in the water increased the organic load of the water and lowered the oxygen content of the water, as a result there was proliferation of the $L$. delbruekii and it became pathogenic to the fish. Fish Doc.2004 observed that when the number or the virulence of the pathogen increases or the host resistance is reduced the pathogen may be able to succeed in attacking the fish. In this study, L. delbruekii number may have increased in the water due to high organic load that resulted in infections of the fish. Similar observation was made with application of Koch's postulate when high concentration of $L$. delbruekii was introduced into the water containing the fish; it killed the fish after two days

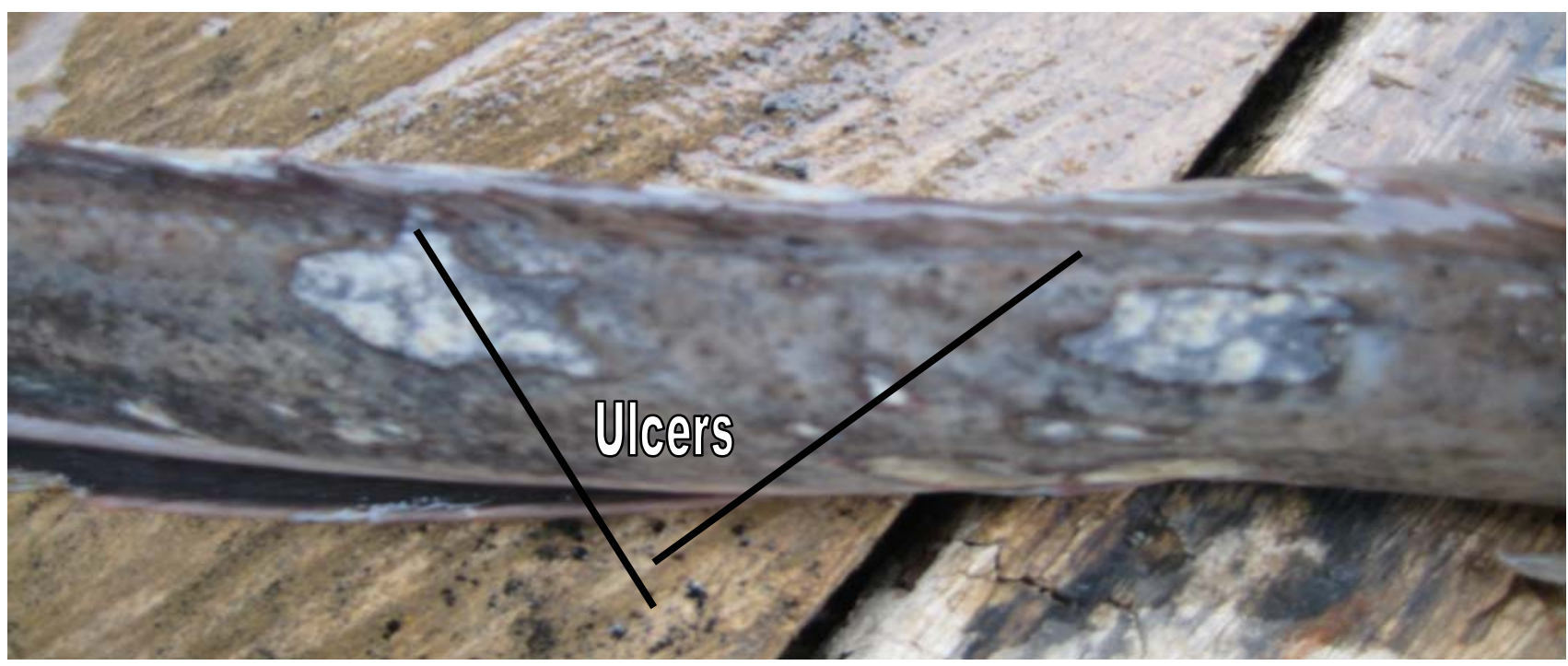

Fig. 1: Ulcers on the skin of Clarias bidorsalis reared in tanks in Ilorin, Nigeria.

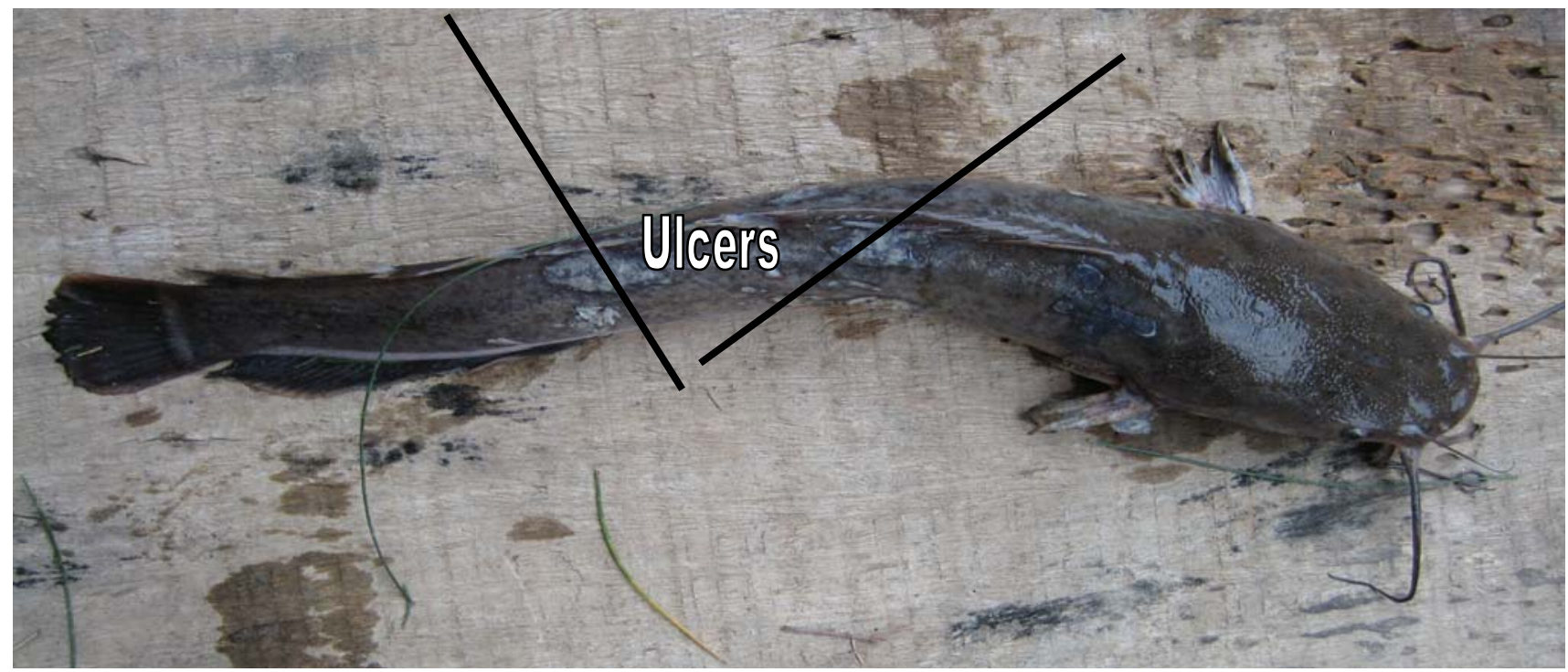

Fig. 2: Showing Clarias bidorsalis with ulcers on the skin. 


\section{REFERENCES}

1. Angka, S.L; Lam, T.J and Sin, Y.M. (1995). Some virulence characteristics of Aeromonas hydrophila in walking catfish (Clarias gariepinus). Aquaculture 130(2-3). Pp. 103-112.

2. Austin, B. (1980). Characterization of the causal agents of bacterial kidney disease. In: Ahne, W. (ed.) Fish diseases.3rd COPRAQ Session. Springer Verlag, Berlin, p. 147-1538.

3. Austin, B and D.A. Allen. (1985). Microbial quality of water in intensive fish rearing. Journal of Applied Bacteriology Symposium Supplement: 207s-226s.

4. Cheesbrough M (1992). Medical Laboratory Manual for Tropical countries. $3^{\text {rd }}$ ed. Tropical Health Technology and Butterworth London.

5. Cone, D. K. (1982). A Lactobacillus sp. from diseased female rainbow trout, Salmo gairdneri Richardson, in Newfoundland, Canada. J. Fish Dis. 5: 479-485

6. Fish Doc(2004) http://www.fish doc.co.uk/index.htm Bacterial infections and diseases common and difficult problems to deal with.

7. Harishi R., Nishai K.S and Mohamed A.A (2003). Prevalence of Opportunistic Pathogens in Paddy Cum Shrimp Farms Adjoining Vembanadu Lake, Kerala, India. Asian Fisheries Science Vol 16:185194
8. Herman, R. L., McAUlster, K., Bullock, G. L., Shotts, E. B., Jr.(1985). Post spawning mortalities of rainbow trout (Salmo gairdneri) associated with Lactobacillus. J. Wildl. Dis. $21.35 \sim 3$

9. Hiu, S. F., Holt, R. A., Sriranganathan, N., Seidler, R. J., Fryer,J. L. (1984). Lactobacillus piscicola, a new species from Salmonid fish. Int. J. syst. Bacteriol. 34: 393-400

10. Holt, J.G, N.R Krieg, P.H.A., Sneath, J.T. Staley and S.T. Williams (1994). Bergey's Manual of Determinative Bacteriology $9^{\text {th }}$ ed. William and Wilkins Baltimore.

11. Michel C., B. Faivre and B. Kerouault (1986). Biochemical identification of Lactobacillus piscicola strains from France and Belgium. Diseases of aquatic organisms. Vol 2:27-30.

12. Oladosu, G.A, O.A Ayinla, M.O Ajiboye (2007). Isolation and pathogenicity of a Bacillus sp. Associated with a septicaemic condition in some tropical fresh water fish species. Journal of Applied Ichthyology. 10(1):69-72

13. Ross, A. J., Toth, R. J. (1974). Lactobacillus. A new fish pathogen? Progve Fish Cult. 36: 19

14. Willey,J.M.Sherwood, L.M and C.J Woolverton(2008)Bacteria:The low G +C gram positive :In Prescott, Harley and Klein's Microbiology.Chapt: 23. Seventh Mc Graw-Hill 